\title{
EKSISTENSI PENGADILAN TINDAK PIDANA KORUPSI MENURUT UNDANGUNDANG NOMOR 46 TAHUN 2009 TENTANG PENGADILAN TINDAK PIDANA KORUPSI TERHADAP PEMBERANTASAN KORUPSI
}

\author{
Dian Eka Prastiwi \\ Fakultas Hukum Universitas Pamulang \\ dianekaunpam@yahoo.com
}

\begin{abstract}
Corruption is an inhibiting factor for the development of democracy, impeding implementation of the tasks of public institutions as well as the misuse of the resources of both natural resources and human resources optimally to the welfare of society. Legal intruments ranging from the Anti-Corruption Act, anti-corruption Institution or the Corruption Eradication Commission (KPK), and a special court that handles cases of corruption referred to the Corruption Court. Of the overall problems that exist Corruption Court was established to resolve the case Corruption is included in the crime of Extra Ordinary Crime. Positionauthority and purpose of the establishment of the Corruption Court is diiatur in Law No 46 of 2009 on the Corruption Court. The existence of the Corruption Court can bring positive thing because it can increase public confidence in the legal institutions in Indonesia.
\end{abstract}

Keywords: corruption Criminal Court, Corruption Eradication Commission, Corruption

\begin{abstract}
ABSTRAK
Korupsi merurupakan faktor penghambat bagi perkembangan demokrasi, menghambat pelaksanaan tugas lembaga-lembaga public serta penyalahgunaan sumber daya yang dimiliki baik sumber daya alam maupun sumber daya manusia secara optimal untuk kesejahteraan masyarakat. Perangkat hukum mulai dari Undang-Undang Anti Korupsi, Lembaga Anti Korupsi atau Komisi Pemberantasan Korupsi (KPK), dan Pengadilan Khusu yang menangani kasus korupsi yang disebut dengan Pengadilan Tindak Pidana Korupsi. Dari keseluruhan masalah yang ada Pengadilan Tindak Pidana Korupsi dibentuk untuk menyelesaikan kasus Tindak Pidana Korupsi yang termasuk dalam kejahatan ExtraOrdinary Crime. Kedudukan, kewenangan dan tujuan dibentuknya Pengadilan Tindak Pidana Korupsi ini diatur dalam Undang-Undang Nomor 46 Tahun 2009 tentang Pengadilan Tindak Pidana Korupsi. Adanya pengadilanTindak Pidana Korupsi ini dapat membawa hal posistif karena dapat meningkatkan kepercayaan masyarakat pada lembaga hukum yang ada di Indonesia.
\end{abstract}

Kata Kunci: Pengadilan Tindak Pidana Korupsi, Komisi Pemberantasan Korupsi, Tindak Pidana Korupsi 


\section{PENDAHULUAN}

Korupsi, Kolusi dan Nepotisme merupakan sumber malapetaka dalam suatu rezim. Korupsi sendiri secara umum adalah penyalahgunaan kewenangan yang ada pada pejabat atau pegawai demi keuntungan pribadi, keluarga atau kelompok (Maheka, 2006 : 2). Korupsi berasal dari bahasa latin Corrupere atau Corruptus yang diambil dari kata harafiah adalah penyimpangan dari kesucian. Tindakan korupsi dikatakan sebagai perbuatan yang tidak bermoral, kejahatan, kerusakan, dan ketidaak jujuran. Dengan demikian korupsi memiliki konotasi adanya tindakan hina, fitnah atau hal-hal buru lainnya. Perkembangan masalah korupsi di Indonesia semakin betambah besar karena sudah menjangkit dan menyebar diseluruh lapisan masyarakat. Selama beberapa tahun berturut-turut Indonesia tergolong negara paling korup di Asia.

Upaya pemberantasan korupsi banyak yang gagal karena pendekatan yang digunakan semata-mata bersifat pendekatan hukum atau terlalu bertumpu pada himbauan moral. Didalam sebuah negara demokrasi korupsi merupakan ancaman yang terus menerus. Tindak Pidana Korupsi dapat mempersulit pembangunan ekonomi dan membuat distorsi dan ketidak efisienan yang tinggi pada sektor dunia usaha. Korupsi meningkatkan ongkos dengan pejabat dan resiko pembatalan perjanjian karena dilakukannya penyidikan (Hadjon, 2011 : 93-98).

Korupsi juga merupakan faktor penghambat bagi pengembangan demokrasi, menghambat tugas lembagalembaga public serta penyalahgunaan sumber daya yang dimiliki. Korupsi sendiri memupuk perilaku merahasiakan segala sesuatu. Kerahasiaan bisa terlihat dari banyaknya pelaksanaan program pembangunan yang memiliki permasalahan masing-masing dimulai dari pengajuan anggaran yang diperbesar (mark-up) dan penggunaan anggaran yang diperkecil (mark-down).

Secara realitas korupsi banyak sekali menimbulkan kerugian. Lebih dari itu kerugian terbesar dari pelaksanaan korupsi yang terus menerus adalah terciptanya kemiskinan secara struktural dan hilangnya kepercayaan masyarakat terhadap lembaga-lembaga negara.

Oleh karena itu mengingat perilaku korupsi yang semakin merajalela yang pada akhirnya akan membawa dampak pada terlambatnya penyelenggaraan kesejahteraan rakyat maka salah satu cara supaya rakyat dapat hidup sejahtera adalah melalui upaya pemberantasan korupsi. Untuk melakukan perlawanan terhadap korupsi pemerintah telah mempersiapkan segala perangkat hukum yang cukup memadai baik dari proses pencegahan maupun pada tingkat pendekatan.

Berdasarkan amandemen ke tiga Undang-undang Dasar mencantumkan lingkungan peradilan yaitu peradilan umum, peradilan tata usaha negara, peradilan militer dan peradilan agama. Meskipun demikian pembentukan pengadilan khusus sangat dimungkinkan. Ketentuan ini ditegaskan dalam UndangUndang Nomor 48 Tahun 2009 tentang Kekuasaan Kehakiman. Pemeriksaan perkara korupsi dalam lingkungan peradilan umum yang sekarang ini dinilai berjalan tidak efektif. Sikap masyarakat terhadap pemeriksaan korupsi di pengadilan umum sekarang ini lebih banyak menunjukkan sikap pesimistis. Masyarakat berpandangan pengadilan yang memeriksa perkara korupsi sekarang ini dipandang belum mandiri dan bebas dari campur tangan pihak lain. Pembentukan pengadilan korupsi juga dalam rangka memenuhi tuntutan perlakuan secara adil dalam memberantas korupsi, jaminan kepastian hukum, dan 
perlindungan hak-hak sosial dan ekonomi masyarakat.

Pembentukan pengadilan korupsi harus dilihat dalam perspektif kebijakan atau politik hukum pidana. Melaksanakan politik hukum pidana berarti mengadakan pemilihan untuk mencapai hasil perundang-undangan pidana yang paling baik dalam arti memenuhi syarat keadilan dan daya guna. Dengan demikian baik dari perspektif yuridis normative maupun sosiologis, terdapat alasan yang cukup kuat untuk tetap mempertahankan eksistensi Pengadilan Khusus Tindak Pidana Korupsi. Disamping itu juga secara yuridis konstitusional, keberadaan Pengadilan Tindak Pidana Korupsi harus berada pada salah satu dari empat lingkungan peradilan, dalam hal ini dibawah lingkungan peradilan umum. Agar tujuan tercapai penempatan Pengadilan Tindak Pidana Korupsi dibawah peradilan umum harus tetap memperhatikan kekhususan yang dimilikinya.

\section{METODE PENELITIAN}

Dalam tulisan ini penulis menggunakan metode penelitian hukum normatif. Menurut Soerjono Soekanto dan Sri Mamuji penelitian hukum normatif atau disebut juga penelitian hukum kepustakaan adalah Penelitian hukum yang dilakukan dengan cara meneliti bahan pustaka atau dara sekunder (HS, 2014 : 12). Artinya bahan pustaka merupakan bahan yang berasal dari sumber hukum primer meliputi: buku, laporan penelitian, disertasi dan sebagainya. Sedangkan bahan hukum sekunder meliputi abstrak, indeks, biografi dan sebagainya.

Pendekatan dalam tulisan ini adalah pendekatan konseptual (conceptual approach) yaitu beranjak dari pandangan-pandangan dan dokrin-dokrin yang berkembang didalam ilmu hukum. Teknik pengumpulan data dalam tulisan ini menggunakan studi dokumenter, maka analisi data dalam tulisan ini adalah analisis kualitatif yang mencoba memberikan gambaran-gambaran atas temuan-temuan, dan karenanya ia lebih mengutamakan mutu atau kualitas dari data dan bukan kuantitas.

\section{PERMASALAHAN}

Berdasarkan latar belakang yang telah diuraikan tersebut, pokok permasalahan dalam tulisan ini adalah Bagaimana kewenangan Pengadilan Tindak Pidana Korupsi dalam sistem Peradilan Hukum Pidana di Indonesia dihubungkan dengan Undang-Undang Nomor 46 Tahun 2009 tentang Pengadilan Tindak Pidana Korupsi dalam Upaya Pemberantasan Korupsi?

\section{PEMBAHASAN}

Secara asas ketentuan hukum pidana dapat diklarifikasikan menjadi Hukum Pidana Umum dan Hukum Pidana Khusus. Ketentuan Hukum Pidana Umum dimaksudkan berlaku secara umum seperti yang diatur dalam Kitap Undang-Undang Hukum Pidana (KUHP), sedangkan ketentuan Hukum Pidana Khusus dimaksudkan sebagai ketentuan pidana yang mengatur tentang kekhususan subjeknya dan perbuatan khusus. Tujuan pengaturan terhadap tindak pidana yang bersifat khusus adalah untuk mengisi kekurangan ataupun kekosongan hukum yang tidak tercakup pengaturannya dalam Kitap UndangUndang Hukum P/ idana. Penerapan ketentuan pidana khusus dimungkinkan berdasarkan pada asas Lex Spesialis Derogat Lex Generalis yang mengisyaratkan bahwa ketentuan yang bersifat khusus akan lebih diutamakan daripada ketentuan yang bersifat umum.

Dijelaskan didalam Law Online Lybrary bahwa Hukum Tindak Pidana Khusus mengatur perbuatan tertentu yang tidak dapat dilakukan oleh orang lain 
selain orang tertentu. Oleh karena itu Hukum Tindak Pidana Khusus harus disubtansikan dan berlaku kepada siapa yang akan menjadi objeknya. Hukum Tindak Pidana Khusus ini diatur dalam Undang-Undang diluar Hukum Pidana Umum. Penyimpangan ketentuan hukum pidana yang terdapat didalam UndangUndang Pidana merupakan indikaror apakah Undang-Undang Pidana itu merupakan Hukum Tindak Khusus ataukah bukan.

Tindak Pidana Korupsi merupakan salah satu bagian dari hukum pidana khusus, disamping mempunyai spesifikasi tertentu yang berbeda dengan hukum pidana umum yaitu dengan adanya penyimpangan hukum pidana formil atau hukum acara.Keberadaan Tindak Pidana Korupsi dalam hukum positif Indonesia sebenarnya sudah ada sejak lama yaitu sejak berlakunya Kitab Undang-Undang Hukum Pidana sebagai suatu kondifikasi dan unifikasi berlaku bagi semua golongan di Indonesia sesuai dengan asas konkondansi dan diundangkan dalam Staatblad 1915 Nomor 752 tanggal 15 Oktober 1915.

Perbuatan Tindak Pidana Korupsi merupakan pelanggaran terhadap hak-hak sosial dan hak-hak ekonomi masyarakat, sehingga Tindak Pidana Korupsi tidak dapat lagi digolongkan sebagai kejahatan biasa melainkan sebagai kejahatan luar biasa (extra ordinary crimes). Sehingga dalam upaya pemberantasannya tidak lagi dapat dilakukan secara biasa tetapi dituntut cara-cara yang luar biasa. Dijelaskan oleh Romli Atmasasmita tentang kondisi tindak Pidana Korupsi di Indonesia sehingga dalam menangani pemberantasan tindak pidana korupsi ini telah merupakan perbuatan yang extra ordinary crimes sehingga perlu dibentuk suatu lembaga pemberantasan tindak pidana korupsi.

Korupsi di Indonesia sudah merupakan kejahatan yang luar biasa, sehingga tuntutan ketersediaan perangkat hukum yang sangat luar biasa dan canggih serta kelembagaan yang menangani korupsi tersebut tidak dapat dielakkan lagi. Tindak Pidana Korupsi seperti yang didefinisikan menurut Undang-Undang Nomor 31 Tahun 1991 tentang Pemberantasan Tindak Pidana Korupsi sebagaimana telah diubah dengan Undang-Undang Nomor 20 Tahun 2001 tentang Pemberantasan Tindak Pidana Korupsi yang memuat pengertian korupsi yang hampir identik dengan pengertian Tindak Pidana Korupsi (Tipikor)

Subjek hukum tindak pidana korupsi berdasarkan Pasal 1 ayat 1,2,dan 3 Undang-Undang Nomor 31 Tahun 1999 jo. Undang-Undang Nomor 20 Tahun 2001 yang dapat dikategorikan sebagai subjek dalam hukum tindak pidana korupsi adalah korporasi, pegawai negeri dan setiap orang. Permasalahan mengenai ruang lingkup tindak pidana korupsi mengalami perluasan delik tindak pidana. Perluasan tersebut pada rumusan dalam penafsiran artinya melawan hukum. Didalam Undang-Undang Nomor 31 Tahun 1999 jo. Undang-Undang Nomor 20 Tahun 2001 menyatakan bahwa Tindak Pidana Korupsi dikategorikan kedalam delik formal, namun didalam pengertian melawan hukum dalam suatu Tindak Pidana Korupsi sebagai delik formal dan delik materiil.

Sebagai delik formal maka suatu perbuatan dapat dinyatakan sebagai Tindak Pidana. Jika perbuatan tersebut telah memenuhi rumusan delik dalam Undang-Undang tanpa harus menimbulkan akibat yang merugikan. Jadi meskipun perbuatan itu belum sampai menimbulkan kerugian keuangan negara tetapi jika perbuatan itu telah dapat dikategorikan kerugian negara maka pelakunya sudah dapat dihukum. Begitupun hasil Tindak Pidana Korupsi telah dikembalikan kepada negara akan tetapi tidak menghapuskan sifat melawan 
hukum atas perbuatan tersebut. Sementara pengertian sifat melawan hukum formal dan materiil menunjuk pada suatu perbuatan tidak hanya bertentangan dengan peraturan perundang-undangan yang berlaku tetapi juga merupakan perbuatan tercela dan bertentanagn dengan perasaan keadilan masyarakat.

Sifat melawan hukum formal dan materiil ini terkandung didalam UndangUndang Nomor 31 Tahun 1999 jo. Undang-Undang Nomor 20 Tahun 2001 sebagaimana yang dirumuskan didalam pengertian "Suatu perbuatan dikatakan melawan hukum didalam pengertian formil dan materiil, bilamna tindak pidana korupsi tersebut mencakup kedalam perbuatan-perbuatan tercela yang menurut perasaan keadilan masyarakat harus dituntut dan dipidana.

Maka dengan melihat pada UU No. 31 Tahun 1999 jo. UU No. 20 Tahun 2001 ruang lingkup Tindak Pidana Korupsi dapat dikelompokkan kedalam beberapa rumusan delik sebagai berikut:

1. Kelompok delik atau Tindak Pidana Korupsi yang dapat merugikan keuangan atau perekonomian negara. (Pasal 2 dan 3 UU No. 31 Tahun1999)

2. Kelompok delik atau Tindak Pidana Korupsi Penyuapan baik yang aktif (yang menyuap) maupun pasif (yang menerima suap). (Pasal 5,6,11,12 dan 12B UU No. 20 Tahun 2001)

3. Kelompok delik atau Tindak Pidana Korupsi Penggelapan (Pasal 8,9, dan 10 UU No. 20 Tahun 2001)

4. Kelompok delik atau Tindak Pidana Korupsi pemerasan dalam jabatan (Pasal 12e dan $\mathrm{f}$ UU No. 20 Tahun 2001)

5. Kelompok delik atau Tindak Pidana Korupsi yang berkaitan dengan perbuatan curang
(Pasal 7 UU No. 20 Tahun 2001)

6. Benturan kepentingan dalam Pengadaaan (Pasal 12 huruf I UU No. 20 Tahun 2001)

7. Gratifikasi (Pasal 12B UU No. 20 Tahun 2001)

Menurut Undang-undang Nomor 20 Tahun 2001 tentang Pemberantasan Tindak Pidana Korupsi. Ada beberapa jenis tindakan yang dikategorikan sebagai tindak korupsi, keugian negara, suap menyuap (sogok atau pencicilan), penggelapan dalam jabatan, Pemerasan, Perbuatan Curang, Bantuan kepentingan dalam pengadaan atau gratifikasi (Pemberian Hadiah). Ada beberapa macam jenis korupsi antara lain:

a. Korupsi Transaktif, jenis korupsi ini disebabkan oleh adanya kesepakatan timbal balik antara pihak pemberi dan pihak penerima demi keuntungan kedua belah pihak dan secara aktif mereka mengusahakan keuntungan tersebut.

b. Korupsi yang memeras, pemerasan adalah korupsi dimana pihak pemberi dipaksa menyerahkan uang suap untuk mecegah kerugian yang sedang mengancam dirinya, kepentingan atau sesuatu yang mengancamnya.

c. Korupsi defensif, orang bertindak menyeleweng karena jika tidak dilakukannya, urusan akan terlambat atau terhenti (prilaku korban korupsi dengan pemerasan jadi korupsinya dalam rangka mempertahankan diri)

d. Korupsi invensif, pemberian barang atau jasa tanpa memperoleh keuntungan tertentu selain keuntungan yang masih diangan-anganatau 
yang dibayangkan akan diperoleh dimasa mendatang.

e. Korupsi perkerabatan atau nepotisme, jenis ini meliputi penunjukan secara tidak sah kepada sanak keluarga atau teman dekat untuk mendapatkan jabatannya dalam pemerintahan, imbalan yang bertentangan dengan norma dan peraturan itu mungkin dapat berupa uang, fasilitas khusus, dan sebagainya.

f. Korupsi otogenik, bentuk korupsi yang tidak melibatkan orang lain dan pelakunya hanya satu orang saja.

g. Korupsi dukungan, korupsi yang dilakukan untuk melindungi atau memperkuat korupsi yang sudah ada maupun yang akan dilaksanakan.

Korupsi sendiri dapat terjadi karena kurangnya transparansi dipengambilan keputusan, lingkungan yang tertutup yang mementingkan dirinya sendiri dan jaringan (teman/kelompok), lemahnya sosialisasi dan penyuluhan hukum kepada masyarakat, adanya kesempatan, lemahnya ajaran agama dan etika. Pengaturan mengenai Tindak Pidana Korupsi ini memiliki kekhususan tersendiri dibandingkan dengan hukum tindak pidana khusus yang lain. Kekhususan yang dimaksud tidak bisa dilepaskan dari keberadaan peraturan perundang-undangan utama yang mengatur tentang Tindak Pidana Korupsi di Indonesia yaitu:

a. Undang-Undang No. 20 Tahun 2001 tentang Perubahan atas Undang-Undang No. 31 Tahun 1999 tentang Pemberantasan Tindak Pidana Korupsi. b. Undang-Undang No. 30 Tahun 2002 tentang Komisi Pemberantasan Korupsi.

c. Undang-Undang Nomor 49 Tahun 2009 tentang Pengadilan Tindak Pidana Tindak Pidana Korupsi.

Kedudukan Pengadilan Tindak Pidana Korupsi

Kedudukan Pengadilan Tindak Pidana Korupsi dalam Sistem Pengadilan Pidana di Indonesia setelah diundangkanya Undang-Undang Nomor 46 Tahun 2009 tentang Pengadilan Tindak Pidana Korupsi membangun atau membentuk sistem hukum di Indonesia tidak dapat diartikan bahwa hingga saat ini tidak ada sistem hukum. Tidak adanya masyarakat tanpa sistem hukum tetapi sistem hukum yang ada belum mencerminkan satu kekuasaan sistem sebagai satu sistem nasional. Mahkamah Agung sendiri sebagai pelaksana kekuasaan kehakiman tertinggi dalam upaya melaksanakan keputusan konstitusi dan reformasi telah dilakukan perubahan atas Undang-Undang Nomor 14 Tahun 1985 dengan Undang-undang Nomor 5 Tahun 2004 tentang tentang kekuasaan kehakiman dan kebijakan mengenai Mahkamah Agung yang mengatur tentang segala urusan mengenai peradilan baik yang menyangkut bidang teknik maupun non teknik.

Kedudukan Pengadilan Tindak Pidana korupsi dalam sistem peradilan dalam rangka mewujudkan supremasi hukum. Dijelaskan dalam Pasal 2 UndangUndang Nomor 46 Tahun 2009 tentang Pengadilan Tindak Pidana Korupsi yang merupakan Pengadilan khusus yang berada dibawah lingkungan Peradilan Umum. Ini berarti bahwa Pengadilan Tindak Pidana Korupsi berada dilingkungan Peradilan Umum sebagai Pengadilan Khusus sehingga kedudukannya akan sama dengan Pengadilan khusus lainnya yang sudah 
dahulu ada seperti Pengadilan HAM. Namun kedudukannya lebih luass dibandingkan dengan pengadilanpengadilan lainnya karena Pengadilan Tindak Pidana Korupsi akan ada disetiap Pengadilan Negeri sebagaimana yang dijelaskan dalam Pasal 3 Undang-undang Nomor 46 Tahun 2009 tentang Pengadilan Tindak Pidana Korupsi. Hal ini juga akan menimbulkan konsekuensi bagi Komisi Pemberantasan Korupsi untuk membentuk perwakilannya disetiap daerah. Sebab jika tidak dilakukan akan menghambat proses baik penyelidikan, penuntutan dan persidangan di Pengadilan yang ada disetiap daerah.

Pembentukan Pengadilan Tindak Pidana Korupsi ditiap-tiap daerah adalah realisasi dari Pasal 54 ayat 3 Undangundang Nomor 30 Tahun 2002. Didalam Pasal 54 ayat 2 disebutkan untuk pertama kalinya Pengadilan Tindak Pidana Korupsi dibentuk pada Pengadilan Negeri Jakarta Pusat yang wilayah hukumnya meliputi seluruh wilayah Negara Republik Indonesia. Sedangkan dijelaskan didalam Pasal 3 disebutkan pula bahwa pembentukan Pengadilan Tindak Pidana Korupsi sebagaimana yang disebutkan didalam Pasal 2 diajukan secara bertahap dengan Keputusan Presiden. Pengadilan Tindak Pidana Korupsi bertugas dan berwenang mengadili, memeriksa dan memutus perkara Tindak Pidana Korupsi yang penuntutannya diajukan oleh Komisi Pemberantasan Korupsi.

$$
\text { Selanjutnya berdasarkan }
$$

Keputusan Presiden Nomor 59 Tahun 2004 tentang Pembentukan Pengadilan Tindak Pidana Korupsi pada Pengadilan Negeri Jakarta Pusat yang daerah hukumnya meliputi seluruh Wilayah Negara Republik Indonesia. Pengadilan Tindak Pidana Korupsi dalam hal ini juga berwenang memeriksa dan memutus tindak pidana korupsi yang dilakukan diluar wilayah Negara Republik Indonesia. Adapun pembiayaannyayang diperlukan dalam rangka pembentukan dan pengadaan sarana dan prasaranan Pengadilan Tindak Pidana Korusi dibebankan kepada anggaran Mahkamah Agung.

Kedudukan Pengadilan Tindak Pidana Korupsi ini berada disetiap ibu kota kabupaten atau kota yang daerah hukum Pengadilan negeri yang bersangkutan, berdasarkan pada Pasal 35 ayat 1 Undang-undang Nomor 46 Tahun 2009 tentang Pengadilan Tindak Pidana Korupsi.

Kewenangan Pengadilan Tindak Pidana Korupsi.

Pengadilan Tindak Pidana Korupsi merupakan satu-satunya Pengadilan yang berwenang memeriksa, mengadili dan memutus perkara Tindak Pidana Korupsi. Yang dimaksud 'satu-satunya pengadilan' disini adalah pengadilan yang memeriksa, mengadili dan memutus perkara yang penuntutannya diajukan oleh Penuntut Umum. Pengadilan Tindak Pidana Korupsi sendiri berwenang memeriksa, mengadili dan memutus perkara:

1. Tindak Pidana Korupsi yaitu Tindak Pidana Korupsi yang sebagaimana yang dimaksud didalam Undang-undang Nomor 31 Tahun 1999 tentang Pemberantasan Tindak Pidana Korupsi yang diubah dalam Undangundang Nomor 20 Tahun 2001.

2. Tindak Pidana Pencucian Uang yang tindak pidana asalnya adalah Tindak Pidana Korupsi yaitu Tindak Pidana sebagaimana yang dimaksud didalam Undang-undang Nomor 15 Tahun 2002 tentang Tindak Pidana Pencucian Uang sebagaimana yang 
diubah dengan Undangundang Nomor 25 Tahun 2003.

3. Tindak Pidana yang secara tegas didalam Undangundang lain ditentukan sebagai Tindak Pidana korupsi.

Dari adanya kewenangan Pengadilan Tindak Pidana Korupsi yang telah disebutkan diatas didalam sebuah sistem peradilan pidana memerlukan kombinasi yang serasi antar antar subsistem untuk mencapai satu tujuan. Sinkronisasi didalam sistem peradilan pidana ini akan lebih memudahkan semua subsistem didalam menjalankan fungsinya dan juga bekerjanya sistem peradilan secara sehat untuk mencapai tujuan keterpaduan antara subsistem didalam penegakan hukum menjadi penentu efektifitas suatu peraturan. Sistem hukum ini akan berjalan baik untuk mencapai tujuan jika semua unsur saling melengkapi dan mendukung.

Meskipun didalam masing-masing komponen subsistem memiliki fungsi dan kewenangan yang berbeda tetapi didalam kerangka sistem peradilan pidana masingmasing subsistem mempunyai tujuan yang sama. Keterkaitan keberhasilan kerja masing-masing subsistem satu dengan yang lainnya akan berdampak pada hasil kerja subsistem yang lainnya dalam menegakkan hukum dan keadilan. Kebutuhan akan aparat penegak hukum untuk menjalankannya. Dengan kewenangan yang diharapkan dapat digunakan untuk memerangi kejahatan yang terjadi didalam masyarakat serta masyarakat merasa aman dan terpercaya kepada sistem peradilan didalam menyelesaikan kasus-kasus yang dihadapi.

Mengenai soal peralihan kasus korupsi yang sebelumnya ditangani oleh Pengadilan Negeri tidak ada tumpang tindih antara perkara yang masuk ke Pengadilan Tindak Pidana Korupsi dan ke
Pengadilan Negeri selama proses pembentukan Pengadilan Tindak Pidana Korupsi. Setelah berlakunya UndangUndang Nomor 46 Tahun 2009 mengenai Pengadilan Tindak Pidana Korupsi maka tidak ada lagi satupun perkara korupsi yang masuk keranah Pengadilan Negeri. Ketika berkas perkara sudah masuk ke Pengadilan Negeri maka akan tetap dilanjutkan dan untuk proses banding dapat diajukan ke Pengadilan Tinggi Tindak Pidana Korupsi. Dijelaskan didalam Pasal 34b UU No. 46 Tahun 2009 mengenai Pengadilan Tindak Pidana Korupsi yang sedang diperiksa pada setiap tingkat pemeriksaan akan tetap diperiksa dan diadili sampai perkara Tindak Pidana Korupsi tersebut tetap diputus sesuai dengan peraturan perundang-undangan dan tetap ditangani oleh Pengadilan Negeri.

Apabila saat berlakunya UndangUndang tersebut Perkara Korupsi sudah masuk ke Pengadilan Negeri maka perkara tersebut dapat dilanjutkan oleh Pengadilan Negeri. Jadi dalam hal ini tidak ada tumpang tindih perkara yang ditangani antara Pengadilan Tindak Pidana Korupsi dan Pengadilan Negeri. Lembaga peradilan khususnya peradilan umum merupakan lembaga pemutus perkara yang dilimpahkan oleh kejaksaan, sedangkan pengadilan Ad-Hoc tindak pidana korupsi memutus perkara yang limpahkan dari Komisi Pemberantasan Korupsi (KPK). Eksistensi lembaga peradilan umum tanpak dalam UndangUndang No. 8 Tahun 2004 tentang Peradilan Umum dan Pengadilan Ad-Hoc yang sesuai dengan Undang-Undang No. 30 Tahun 2002 tentang Komisi Pemberantasan Korupsi (KPK). Pada lembaga Peradilan Umum dan Pengadilan Ad-Hoc kasus korupsi terdakwa diperiksa, diadili dan diputus oleh majelis hakim. Berdasarkan data terakhir diseluruh Indonesia untuk peradilan umum terdapat kurang lebih 30 Pengadilan Tinggi, 
kemudian untuk Pengadilan Negeri kurang lebih 324 pengadilan.

Undang-Undang Nomor 46 Tahun 2009 tentang Pengadilan Tindak Pidana Korupsi diatur mengenai kewenangan Pengadilan Tindak Pidana Korupsi yang terdapat dalam Pasal 5 disebutkan bahwa Pengadilan Tindak Pidana Korupsi merupakan satu-satunya pengadilan yang berwenang memeriksa, mengadili, dan memutus perkara tindak pidana korupsi artinya Peradilan umum sudah tidak mempunyai wewenang lagi untuk menyidangkan perkara-perkara korupsi.

Wewenang untuk mengadili semua perkara korupsi ini akan membuat proses penegakan hukum kasus korupsi lebih memberikan kepastian hukum dan tidak diskriminatif. Dan pastinya dualisme dalam sistem peradilan tindak korupsi dapat diakhiri. Disampaikan pula mengenai kekhusan Komisi Pemberantasan Korupsi (KPK) didalam menangani Tindak Pidana Korupsi sebab tidak semua kasus korupsi ditangani oleh Komisi Pemberantasan Korupsi, ada juga beberapa karakter tertentu bagi Komisi Pemberantasan Korupsi (KPK) untuk menangani sebuah kasus korupsi. Kasus yang ditangani oleh Komisi Pemberantasan Korupsi (KPK) adalah kasus yang secara signifikan besar dan syaratnya adalah sebagai berikut (Adji, 2002 : 113 ):

1. Menyangkut pelanggaan hukum oleh penyelenggara Negara atau penegak hukum dan pihak-pihak yang bersangkutan dengan pelanggaran hukum itu

2. Menarik perhatian dan meresahkan masyarakat.

3. Nilainya lebih dari Rp. 1.000.000.000 (satu milyar) atau lebih.

Dengan dibentuknya Pengadilan Tindak Pidana Korupsi di Indonesia maka terlihat jelas bahwa Pemerintah mulai berupaya untuk melakukan perbaikanperbaikan dalam hal pencegahan dan pemberantasan korupsi secara struktural. Yang secara yuridis diatur bahwa Pengadilan Tindak Pidana Korupsi berada dilingkungan Peradilan Umum. Ketentuan ini memiliki korelasi yang sangat kuat dengan UUD RI 1945 perubahan ke-3 Pasal 24 ayat 1 yang berisi Kekuasaan Kehakiman merupakan kekuasaan yang merdeka untuk menyelenggarakan peradilan guna menegakan hukum dan keadilan. Ketentuan yang ada dalam Pasal 15 ayat (1) Undang-Undang Nomor 48 Tahun 2009 tentang Kekuasaan Kehakiman. Untuk meningkatkan fungsi dan peranan putusan pengadilan agar dapat mengimbangi fungsi dan peranan peraturan perundang-undangan dalam mewujudkan kesejahteraan rakyat maka jaminan terhadap kemandirian dan kemerdekaan hakim untuk menentukan pola pikir dan sikap tindak dalam konstruksi suatu putusan pengadilan sangatlah penting.

Dengan adanya pengaturan mengenai mekanisme dissenting opinion dalam suatu putusan pengadilan yang diatur dalam Undang-Undang No. 48 Tahun 2009 tentang Kekuasaan Kehakiman. Undang-Undang Nomor 5 Tahun 2004 tentang Perubahan Atas Undang-Undang Nomor 14 Tahun 1985 tentang Mahkamah Agung, dan Peraturan Mahkamah Agung Republik Indonesia Nomor 2 Tahun 2000 tentang Penyempurnaan Peraturan Mahkamah Agung Nomor 3 Tahun 1999 tentang Hakim Ad Hoc, hal ini merupakan suatu langkah yang progresif dalam penyelenggaraan kekuasaan kehakiman di Indonesia dimana kedaulatan hakim dalam suatu putusan Pengadilan yang dahulu bersifat kolektif dan tertutup kini kini bersifat individual dan terbuka guna meningkatkan transparasi dan profesionalitas penyelenggaraan kekuasaan kehakiman di Indonesia. 


\section{PENUTUP}

\section{Kesimpulan}

Dari uraian diatas dapat maka dapat dipahami bahwa kewenangan Pengadilan Tindak Pidana Korupsi didalam sistem Peradilan Indonesia setelah diundangkannya Undang-Undang Nomor 46 Tahun 2009 tentang Pengadilan Tindak Pidana Korupsi didalam hal ini sebagai sistem peradilan pidana dalam rangka mewujudkan supremasi hukum. Pemerintah sendiri telah meletakkan landasan kebijakan tersebut tertuang didalam Ketetapan Majelis Permusyawaratan Rakyat Indonesia Nomor XI/MPR/1998 tentang Penyelenggaraan Negara yang bersih dan bebas dari tindakan Korupsi, Kolusi dan Nepotisme. Oleh sebab itu pemmerintah membentuk Pengadilan Tindak Pidana Korupsi yang merupakan satu-satunya Pengadilan yang berwenang memeriksa, mengadili, dan memutus Perkara Tindak Pidana Korupsi. Yang dimaksud satusatunya pengadilan disini adalah Pengadilan yang memeriksa, mengadili dan memutus perkara yang penuntutannya diajukan oleh Penuntut Umum.

\section{Saran}

Diharapkan pemerintah, Preaktisi dan Akademisi dapat memberikan kontribusi didalam sosialisasi mengenai Pengadilan Tindak Pidana Korupsi serta penyelesaian sengketanya dalam kewenangan Pengadilan Tindak Pidana Korupsi sebagai unifikasi hukum yang kini telah ada dasar hukum pembentukannya yang diatur didalam Undang-undang Nomor 46 Tahun 2009 tentnag Pengadilan Tindak Pidana Korupsi yang merupakan bagian dari sistem kekuasaan kehakiman yang berada dibawah Sistem Peradilan Pidana.

\section{DAFTAR PUSTAKA}

Adji, Indriyanto Seno, Korupsi dan Hukum Pidana, Gramedia, Jakarta, 2002

Arya Maheka, Menggalli dan Memberantas Korupsi, Komisi Pemberantasan Korupsi, Jakarta, 2006

Hamid, Hamrad dan M. Husein, pemberantasan Permasalahan KUHAP Bidang Penyelidikan, Sinar Grafika, Jakarta, 2004.

Kanter dan S.R. Sianturi, Hukum Pidana Indonesia dan Penerapannya, Alumni AHM-PTHM, Jakarta, 2002.

Philipus M. Hadjon, dkk, Hukum Administrasi dan Tindak Pidana Korupsi, Gajah Mada University Press, Yogyakarta, 2011

Romli Atmasasmita, Good Governance dan Komisi Anti Korupsi di Indonesia, Badan Pembinaan Hukum Nasional dan Hak Asasi Manusia Republik Indonesia, Jakarta, 2004.

Salih HS, et.al., Penerapan Teori Hukum Pada Penelitian Tessis dan Disertasi, Rajawali Pers, Jakarta, 2014

Undang-Undang Dasar 1945

Undang-Undang No. 20 Tahun 2001 tentang Perubahan atas UndangUndang No. 31 Tahun 1999 tentang Pemberantasan Tindak Pidana Korupsi.

Undang-Undang No. 30 Tahun 2002 tentang Komisi Pemberantasan Korupsi.

Undang-Undang Nomor 49 Tahun 2009 tentang Pengadilan Tindak Pidana Tindak Pidana Korupsi. 